\title{
Multiracial Classification on the United States
}

\section{Census}

Myth, Reality, and Future Impact

\section{Ann Morning}

\section{(2) OpenEdition}

\section{Journals}

Electronic version

URL: https://journals.openedition.org/remi/2495

DOI: $10.4000 /$ remi.2495

ISSN: $1777-5418$

\section{Publisher}

Université de Poitiers

Printed version

Date of publication: 1 June 2005

Number of pages: 111-134

ISBN: 2-911627-40-7

ISSN: 0765-0752

\section{Electronic reference}

Ann Morning, "Multiracial Classification on the United States Census", Revue européenne des migrations internationales [Online], vol. 21 - n² | 2005, Online since 01 October 2008, connection on 14 April 2022. URL: http://journals.openedition.org/remi/2495 ; DOI: https://doi.org/10.4000/remi.2495

This text was automatically generated on 14 April 2022

(c) Université de Poitiers 


\title{
Multiracial Classification on the United States Census
}

\author{
Myth, Reality, and Future Impact
}

\section{Ann Morning}

1 The 2000 census in the United States provoked a flurry of media attention in the months leading up to it, as well as in its aftermath. At issue was the new federal decision permitting Americans to identify themselves with more than one race on the census form ${ }^{1}$. Advocated in large part by interracially-married couples and their offspring, this bureaucratic change in racial classification practices was widely interpreted in the press as having a wider significance for the nation as a whole. As one reporter put it, "the change is fueling a weighty debate about the meaning of race" (2000). Other articles spoke to the same thought-provoking effect of the new classification standards: the Washington Post ran "Mixed-Race Heritage, Mixed Emotions: In Census and Society, Question of Categories Yields Many Answers" (Fears, 2001), while Newsday asked, "Does It All Add Up? New Census Race Categories Raise Questions About How They're Used" (Winslow, 2001). According to the latter, "the impact of racial classifications on the latest census has far-reaching implicationssocially, politically, even statistically- that have sown anger, suspicion, uncertainty and excitement in varying quarters."

2 This essay examines the expectations - both positive and negative- that characterized public discourse about the introduction of multiple-race reporting on the 2000 U.S. census. More importantly, I revisit these predictions in order to assess whether they have proved accurate. In so doing, the paper aims for a clear stock-taking of the impact of multiple-race reporting to date: which expectations have been borne out, which have not, and what unforeseen developments seem most likely to be the medium or long-term legacy of the revision of the federal racial standards?

3 I begin by recalling both the benefits and the drawbacks that commentators in the late 1990 s and early 2000s expected from multiple-race classification. With the understanding that some predictions were too long-term to fully assess today, I nonetheless consider each and offer a prognosis. I then extend the discussion to 
consider two potential results of multiple-race reporting that have received less attention: its impact on essentialist or biological interpretations of race, and its implications for the classification of the Hispanic population. In conclusion, I argue that the most widely-publicized hopes and fears about multiracial classification are likely to prove minor outcomes, while the unanticipated consequences may well be more significant.

\section{Background: the (re)introduction of multiracial census classification}

4 In the wake of the civil rights legislation passed in the 1960 s and early 1970 s, the collection of data on race became an important instrument for monitoring the social and economic outcomes of American racial minorities. In 1977, the centrality of this statistical mission propelled the Office of Management and Budget (OMB) to promulgate a set of guidelines on racial classification that was intended to direct the data collection and analysis efforts of all federal agencies, including the Census Bureau2. This guidance, known as Statistical Directive 15, established the following racial categories (Edmonston, Goldstein and Lott, 1996):

- American Indian or Alaska Native

- Asian or Pacific Islander

- Black

- White

5 The OMB did not consider Hispanics to constitute a racial population, but rather an ethnic group; the agency defined Hispanics as persons "of Mexican, Puerto Rican, Cuban, Central or South American or other Spanish culture or origin, regardless of race" (Edmonston, Goldstein and Lott, 1996: 66). This approach, according to which Hispanics "can be of any race" and can only be described racially by using the official OMB categories, remains a feature of the U.S. racial classification standards today.

6 As implemented in census taking and other official data collection efforts, Directive 15 originally did not allow for the multiple designations of individuals: one could be black or white but not both. It was this interpretation of the racial categories as mutually exclusive that would draw public ire and a clamor for a change to the racial standards.

7 In the early 1990s, the bureaucratic regulation Directive 15 became the focus of a public campaign to modify it (Nobles, 2000; Williams Forthcoming). Although many groups mobilized to effect some change in the racial standards- for example, Cape Verdeans and Arab Americans lobbied for their own, separate racial categories (Office of Management and Budget, 1997)- it was the individuals and organizations who formed what has come to be known as the multiracial movement that spearheaded these efforts. Through public hearings and written testimony, a large number of people and organizations pushed the OMB to revise the federal racial classification standards to recognize multiracial identities.

8 The government's response, issued in 1997 in the form of a revision to Statistical Directive 15 (Office of Management and Budget, 1997), both satisfied and frustrated members of the multiracial movement. OMB's decision to permit individuals to select more than one race when describing themselves allowed the recognition of multiple- 
race identities that many had sought. However, OMB's rejection of a single category labeled "Multiracial" was deeply disappointing to some.

Since 1997, the media's treatment of the change in racial classification standards has often conveyed two misunderstandings of the revisions. First, the introduction of multiple-race reporting was not a decision about the U.S. census only; Statistical Directive 15 applies to all federal agencies' data collection.

Second, the 2000 census was not the first to recognize mixed-race groups in the United States. In fact, $19^{\text {th }}$-century national censuses had already done so by enumerating "mulattoes" of European and African ancestry, and "mixed bloods" of European and American Indian origin (Morning, 2003). What was new in the $21^{\text {st }}$ century was instead the recognition of a much wider range of multiracial backgrounds, rather than simply the black/white and red/white combinations that preoccupied earlier generations of European Americans (Forbes, 1993) ${ }^{3}$.

11 This historical amnesia about past national practices of enumerating the mixed-race population is compounded by a related oversight, namely the contention that multiracial people are a new phenomenon in the United States (Morning, 2003; Nobles, 2000). Newspaper articles with titles like "The New Face of America: Blended Races Making a True Melting Pot" (Puente and Kasindorf, 1999) or "A New Generation is Leading the Way: What Young People of Mixed Race Can Tell Us About the Future of Our Children" (Jackson Nakazawa, 2003) sound this theme. This equation of multiraciality with contemporary America overlooks the fact that the nation has a long history of experience with interracial unions, one that stretches back to its colonial antecedents (Sollors, 2000). However, the "one-drop rule" of hypodescent whereby offspring of partial African ancestry were automatically assigned to the "black" category has effaced much of our multiracial history (Davis, 1991). Instead, mixed-race Americans today are usually portrayed in the media as a product of the rising rates of interracial marriage that followed the Supreme Court's 1967 prohibition of state bans on interracial marriage. But if we heed some estimates that three-quarters of the African-American population are of mixed ancestry ${ }^{4}$, and that the Hispanic minority- now the nation's largest- is mostly multiracial, then we can imagine that the share of multiracial America that is made up of today's children of interracial marriages is quite small.

\section{The good side of multiracial classification: dreams of a postracial future}

12 This sense of multiracial newness fostered the optimism that many felt when considering the eventual impact of the 2000 census' introduction of multiple-race reporting. The belief that Americans were witnessing a new social formation led to the hope that it augured a different racial future, one where racial distinctions and strife would vanish.

\section{Multiracialism as Anti-Racism}

13 Implicit in the media's depiction of the 2000 census as "raising questions" about race was the suggestion that the recognition of mixed-race people challenged racist notions in particular. Such traditional biases might include beliefs in the incompatibility of 
races or the "one-drop" rule for treating black ancestry as a definitive taint. Both the existence and the social acceptance of multiraciality were seen as a blow to these longstanding social conventions. In this way, the new census race question was often interpreted as a stand against racism.

There are other reasons that the "new" multiracial population has repeatedly been portrayed as a very special community with real transformative power to call a racismfree America into being. One is that mixed-race people themselves are thought to ignore racial boundaries and be free from racial prejudices. This view has been expressed emphatically by Daniel (2002), who describes "the new multiracial identity" as one that "deconstructs the Eurocentric dichotomy as well as the hierarchical valuation of blackness and whiteness as mutually exclusive and unequal". In other words, mixed-race people have the ability to see behind the veil of racial ideology, rejecting its premises and its divisive effects.

The multiracial population also symbolizes racial tolerance in the public mindset because it is construed as being the product of interracial marriages. By disregarding the United States' early history of multiraciality as the outcome of sexual coercion in conditions of servitude, mixed-race people are now perceived as the offspring of voluntary relations, and the triumph of color-blind love despite some enduring social prejudices 5 . They absolve white Americans of guilt by attesting to the collapse of pernicious race barriers.

The contemporary appeal of the multiracial population also lies in the role as "bridge" or intermediary that is often ascribed to it. This group is supposed to be able to bring distinct racial communities together and smooth over the tensions or misunderstandings between them. The idea of mixed-race people linking separate, if not adversarial, communities is not a new one. In the 1930s, an Osage chief instructed his tribe's mixed bloods:

You have the thoughts of white men, but you have the interests of your people in your hearts...If you let your white man's tongues say what is in your Indian hearts you will do great things for your people (quoted in Wilson, 1992: 120).

In this quotation, the chief portrays his mixed-blood audience as assets for their "people," who are ostensibly Indians, not whites. But his words also demonstrate that the perceived beneficiaries of multiracial mediation vary over time. In his view, mixedbloods could exploit their intermediate status for the benefit of American Indians: "your people." Today, in contrast, the attractiveness of mixed-race people is not for communities of color, but rather for whites. The bridging that multiracial people have to do is not to ameliorate the socioeconomic conditions of people of color- as earlier "mulattoes" like Walter White and Adam Clayton Powell, Jr. did- but to explain and symbolize diversity for the benefit of whites, in an attractive and non-threatening way. Mixed-race people can bring together different racial groups through their good offices, without requiring the hard work that addressing socioeconomic stratificationthe root cause of racial tension- would involve.

18 In the public eye, the mixed-race population is simultaneously the bellwether and the advance guard of a new post racial nation. Multiracial people raise hopes for a new, non-racist America because they are perceived as uniquely suited to unite the rest of us, and bring us together despite the racial antagonism of the past. In short, they are a bridge not just between different racial groups, but also from the present to a colorblind future. 


\section{Burnishing the Multiracial Image} multiracial activists and the media. The latter in particular has burnished the multiracial image through various subtle forms of glorification. One way is to equate racial hybridity with physical beauty; a widely-remarked upon example of this was the multiracial morphed image that Time Magazine placed on its cover in 1993. Dubbedpredictably- the "New Face of America," the resulting female portrait was considered so beguiling as to seduce many of the staff members who helped construct it (Brown, 1997; Gaines, 1993). Streeter (2003) notes the similar equation of multiracial hybridity and beauty in advertising, such as in the case of "rainbow babies" and Benetton publicity. A recent New York Times article on "Generation E.A.: Ethnically Ambiguous" quotes an advertising executive as observing, "Today what's ethnically neutral, diverse or ambiguous has tremendous appeal...Both in the mainstream and at the high end of the marketplace, what is perceived as good, desirable, successful is often a face whose heritage is hard to pin down" (La Ferla, 2003).

The portrayal of hybridity as attractive and appealing is magnified by the media's frequent use of celebrities to illustrate the multiracial phenomenon. Professional golfer Tiger Woods is perhaps the best-known example of this approach, but other celebrities such as the actors Halle Berry and Keanu Reeves, or the singers Prince and Mariah Carey, are regularly mentioned in connection with commentary on the "new" multiracial America ${ }^{6}$.

21 A new entrant in the multiracial celebrity arena is the politician Barack Obama, elected a U.S. senator in 2004. Although he is not the first national political figure of mixed racial ancestry (consider Secretary of State Colin Powell, New Mexico Governor Bill Richardson, or U.S. senator Ben Nighthorse Campbell), he seems to be the first whose multiracial heritage is widely recognized by the public. And as a young man, he is associated with the younger generations that have been more exposed to the discourse of multiraciality (as opposed to one-drop categorization). Like Tiger Woods, Obama has become simultaneously a symbol, a beneficiary, and a victim of his typecasting as biracial. On one hand, his genealogy has become an inevitable element of all political commentary on his career; the media seems unable to discuss him without referring to his black Kenyan father and his white American mother. On the other hand, Obama has been more willing and able than Woods to capitalize on his inescapable pigeonhole; he has authored an autobiography subtitled "A Story of Race and Inheritance" (Obama, 2004), and translated his biracial profile into a political platform emphasizing a unified nation ("There is not a black America and a white America...There's the United States of America"')- a canny move in a time of heightened political polarization. Personifying multiracialism in the public sphere, Obama provides a powerful example of the public association of mixed-race people with bridging divides- not just in love, but between political persuasions and class. As with mixed-race people more generally, Obama's heritage is interpreted as meaning he is part of "a transcending culture," in the words of sociologist Orlando Patterson (quoted in Malcomson, 2004). The apolitical Woods, in contrast, has provoked criticism because his references to his multiracial heritage are perceived as rejecting an African American identity; the astute Obama has taken pains to refer to himself as a black man. Where Woods married a Scandinavian, 
Obama married an African-American woman; personal choices that nonetheless resonate meaningfully with the public audience.

Like the glorification of multiraciality in other arenas, however, becoming the first political poster boy for the "new" multiracial America also depends on the nation's ignoring earlier mixed-race political figures whose hybridity was rooted in the antebellum regime of race mixing. The extension of the multiracial presence to the political arena also achieves its glamour by discounting or obscuring much older multiracial presence. In this connection, it is striking to compare Obama, who gave the Democratic convention keynote address in, 2004, to his predecessor at the keynote podium in the previous 2000 Democratic convention: Harold Ford Jr., Congressman from Tennessee. Although Representative Ford's very light coloring suggests significant non-African ancestry, he was not perceived as a multiracial figure. Similarly, U.S. Secretary of State Colin Powell has not been presented to the public as a mixedrace person. Without interracially-married parents in the background- only generations of "blacks" whose infusion of European ancestry likely dates to the slave epoch- these public persona, no matter how accomplished, cannot carry the banner of multiraciality's promise of a brighter, postracial future. Obama's appeal, in contrast, may rest precisely on the fact that "he is not the direct product of generations of black life in America: he is not black in the usual way" (Malcomson, 2004). In other words, multiraciality's promise of a new start also holds out the prospect of a community of (some) color that is not embittered by past struggles for racial equality; without such grievances, whites need not cope with historical guilt about the enduring racial stratification of U.S. society.

\section{The dark side of multiracial classification}

In stark contrast to the equation of multiracialism with anti-racism, the advent of multiple-race census enumeration also gave rise to a variety of pessimistic predictions. Here I group them into two camps, which I will call (a) the "mulatto escape hatch" faction, and (b) the "civil rights data" concern. Although the two share a common preoccupation with the links between racial classification and racism, they raise very different sets of specific worries.

\section{Multiracialism as the Downfall of Minority Solidarity}

Instead of seeing the multiracial population as a positive force for bridging differenceslet's call it "the Obama model"- some have seen it as a divisive force, which we might call the "Tiger Woods" model. In the latter view, multiracial

identities- and their official recognition in the revised classification standards-

threaten to tear communities of color apart, as multiracial opportunists desert the monoracial camp in search of new prestige and higher status compared to their "fullblood" counterparts of color. Woods' admission that he had at some point thought up the label "Cablinasian"- rather than black or African-American- to describe himself exemplifies this fear that multiracial self-identification is antithetical to a black identity. Like debates about the historical impact of segregation on the AfricanAmerican community, this perspective suggests that an originally racist conventioni.e. the idea that anybody with "one drop" of black blood was black- ultimately had the 
desirable effect of creating a unified black America. The parallel argument about segregation is that it had the positive outcome of keeping middle-class business and services in black neighborhoods, rather than permitting the exodus of middle-class blacks that some believe is linked to contemporary poverty in black neighborhoods.

In the face of the deeply-held personal sentiments that propelled many mixed-race people to lobby for multiracial classification, an equally vehement and emotional opposition to such categorization came from minority groups who feared that the statistical change would siphon off their members. African Americans were particularly vocal on this point, seeing in the multiracial option an "escape hatch from blackness" (Jones, 1994); see also Nelson (2000), Raspberry (1999), and Spencer (1997) ${ }^{8}$. Here the potential injury was twofold: first, a mixed-race exodus from the black community would constitute an insult if not outright betrayal; and second, lower head counts of blacks and Hispanics might have repercussions for their political clout.

\section{Multiracialism and the Machinery of Civil Rights Protection}

26 A less widely discussed concern about multiple-race reporting was that it would damage the official and unofficial system of racial data collection. Here the perceived threat had three dimensions. First, the introduction of 63 possible racial combinations (thanks to more-than-one-race selection) would hamper policymakers and other researchers who wished to study race-related outcomes, thus limiting knowledge of racial stratification in the U.S. A second and related concern was that the complexity of the new race categories might hand ammunition to those detractors who would like to do away with racial statistics altogether. In other words, a racial classification system with 63 categories (or 126 if cross-tabulated by Hispanic origin) might make an easy target for those who want to eliminate such categorization.

And third, some feared that the new multiple-race data would complicate- and consequently weaken- the enforcement of anti-discrimination laws (Perlmann and Waters, 2002). As noted above, the collection of data on race and ethnicity is a major tool in the government's strategy for fighting discrimination in a wide array of realms, such as employment, housing, and credit markets. Such information permits investigators at the Equal Employment Opportunity Commission (EEOC), the Office of Federal Contract Compliance Programs (OFCCP) and other federal agencies to discern patterns of discrimination in such areas as job hiring and promotion or business contract awards. Statistical analyses of the data are regularly employed to determine, for example, whether job candidates of different racial backgrounds but with comparable skills are equally likely to be hired ${ }^{9}$. And for the purpose of such analysis, the rules for assigning individuals to one racial category or another make a difference (Goldstein and Morning, 2002). Roderick Harrison, who likens the post-revision federal racial statistical system to Humpty-Dumpy after his fall, considers the repercussions of the strategy of treating mixed-race people- some of whom may previously been classified as white- as if they belonged to monoracial communities of color for statistical purposes:

Employers, landlords, educational institutions, and health officials in a given locality are likely to object to being held to goals or standards for American Indians, Asians, or African Americans that are 10, 20, or 30 percent higher than they would have been without the methodological revisions. On the other side, those who feel they suffer from inequitable educational, employment, housing, or health 
conditions are also likely to insist that statistics showing improvements in these conditions not reflect new collection and tabulation methods rather than changes that would have been measured in these conditions absent the revisions. (Harrison, 2002: 138)

In other words, if those who are pressing- or being pressed- for reductions in racial socioeconomic inequalities come to believe that the statistical data on which they rely is arbitrary, shaped more by bureaucratic algorithms for classifying individuals racially than by the underlying phenomena they seek to measure, then they may come to challenge not just the accuracy and significance of such statistics, but the wisdom of anti-discrimination laws more broadly.

Together, these concerns led to despair in some quarters that in the wake of the 1997 revision, the official racial classification system would become so unwieldy as to crumble under its own weight.

\section{Actual impact of multiracial classification to date}

Now, from the vantage point of late 2004, it seems that many of the predictions about the impact of the federal government's shift to multiple-race classification- both negative and positive- simply have not come true. Although it is clearly too early to evaluate some of the expectations- most notably, that of a new postracial America- we can begin to trace the outlines of the impact of others. In other words, I question whether the seeds of change for the longer-term predictions seem to be materializing.

\section{The Escape Hatch Thesis}

31 Perhaps the easiest prediction to refute is the "escape hatch" thesis that significant numbers of formerly black people would identify themselves with more than one race on the 2000 census. Of the 36.4 million people who checked off "Black or African American" on the census form, 34.6 million (or 95 percent) selected this category alone; less than five percent added other races to it (Grieco and Cassidy, 2001). Although this is not an insignificant number, it is far from the proportion of African Americans that could probably report some European or American Indian ancestry if they so chose. In 1918, the Census Bureau estimated that 75 percent of the Negro population had nonblack ancestry; more recent estimates also put this share above 50 percent (U.S. Census Bureau, 1918). Moreover, the African-American community emerged as the racial minority group least affected by "multiracial desertion." of the 4.1 million people who checked the "American Indian or Alaska Native" option, fully 1.6 million or 40 percent combined it with other racial designators; and the comparable figure for Asians was 14 percent (Grieco and Cassidy, 2001). Both of these groups have higher outmarriage rates than do African Americans (Pollard and O'Hare, 1999). So although the prospect of mulattoes abandoning the African-American ship touched a prominent nerve in public discourse about the change in federal racial classification, blacks were the community of color least affected by the switch.

The black community's apparent immunity from the lure of multiracialism may change in the future, however. One reason is simply that as intermarriage rates increase, even for blacks, more multiracial children are likely to be born. Another is that conventions about multiple-race identification may change, especially if Madison Avenue and other 
media continue to glorify the appeal of the "ethnically ambiguous." As older people who were used to the one-drop rule for adopting an exclusively black identity pass away, newer generations may be inclined to identify some non-black ancestry, even if they are not the product of interracial unions but instead are pointing to racial mixture much further back in the family tree. The opportunity to identify with more than one race, still new, may become more familiar over time, and more people may take advantage of it. Informal estimates suggest that nearly half the U.S. population could describe itself as mixed-race, considering not just the mixed ancestry of the black, Latino, and American Indian populations, but of the white community as well (Morning, 2000). The noted historian Ira Berlin has remarked that for whites with ancestors in the United States prior to the $19^{\text {th }}$ century, "it's highly likely you will find an African and an American Indian" in the family tree (quoted in Owens, 2004: F4). If these more distant sources of multiracial ancestry came to be validated, a growing share of Americans might identify with more than one race on official forms like the census, regardless of new births to interracial unions.

\section{The Bureaucratic Utilization of Multiple-Race Data}

Just as the "mulatto escape hatch" prediction has not been borne out, apprehensions about the impact of multiple-race reporting on the statistical uses of race data now seem to have been misplaced. It is true that it is perceived in some quarters as a bureaucratic inconvenience. But in a sense, this disgruntlement simply reflects a shift in the burden of racial data collection from the individual respondent, previously unhappy with the choices he or she was forced to make, to the technocrat who must now cope with 63 racial categories. In other words, government officials now suffer the shortcomings of our racial classification standards to a greater extent, but relieve some of the imposition that inadequate categories placed on others.

Still, the fear that the emergence of 63 racial categories would leave the racial classification system so unwieldy as to crumble from its own weight does not seem justified at this point in time. Nor has it handed much ammunition to those detractors who want to do away with racial statistics altogether. Interestingly, the most active movement that aims to eliminate race data- Ward Connerley's Racial Privacy Initiative- has not capitalized on the idea that the categories have become too complex to be workable. In part this may be because the organization advocates the retention of racial data collection for some purposes, like biomedical research and criminal justice.

As a result, nearly halfway through the decennial census cycle, the edifice of racial categorization and statistically-grounded anti-discrimination policies in the U.S. has not given way. This is due in large part to the fact that the federal government has issued guidelines for allocating multiple-race data back to traditional single-race categories in order to facilitate the enforcement of civil rights law (Office of Management and Budget, 2000) ${ }^{10}$. In short, the OMB requires civil rights enforcement agencies to assign each multiple-race response to a single racial group for statistical purposes, and to do so by assigning all people of white and non-white heritage to the non-white group. Although many have remarked on the irony of adopting the one-drop rule for civil rights purposes, the motivation of wanting an inclusive measure of the potentially discriminated-against population has been widely accepted, at least for now. 

civil rights protection agencies- continue to operate with single-race categories explains why so many of the dire predictions about the bureaucratic effects of multiple-race classification have proved unfounded. Its impact has been muted simply because the multiracial person does not yet truly exist for the machinery of government, which continues to use race data to implement single-race laws. This continued official invisibility of multiracialism is mirrored in the fact that under the current allocation rules for assigning mixed-race people to single races, it is not possible to allege that one has suffered discrimination due to one's mixed-race status, but only on the basis of one of the "core" single races of ancestry. Paradoxically, the advent of multiple-race reporting has not introduced the multiracial actor as a protagonist in the implementation of civil rights law. This is all the more ironic because the multiracial movement has often been interpreted as a latter-day civil rights movement (Nobles, 2000; Williams Forthcoming), complete with its own "Bill of Rights for Racially Mixed People" (Root, 1992).

\section{The Expected Benefits of Multiracialism}

racism that its supporters anticipated? Obviously, it is impossible to answer such a question based on barely five years of experience. Nor is it clear how one could link any such trend to a specific event like the census change, even with a much longer time period to investigate. Instead, I consider below the likelihood that today's public discourse about multiraciality contains the seeds of revolutionary new thinking about race.

Some supporters suggest that official multiple-race recognition will erode racism because it undermines the traditional American belief that racial groups are biologically separate entities. That is, they believe biological essentialism is a necessary ingredient for racism ${ }^{11}$ and that multiracial acknowledgment counters such essentialism because it introduces the idea that race is malleable, situational, cultureand time-bound. For example, discussion of multiracial identity raises awareness that a person's self-identified race can be different from the one ascribed to him or her by another person.

41 The likelihood that the new multiracial visibility will radically reshape American understandings of race is, however, limited by several factors. Although academics have begun to describe the racial self-identification choices of multiracial people in order to explore the constructed nature of race identity (e.g. Chew, Eggebeen and 
Uhlenberg, 1989; Harris and Sim, 2002; Rockquemore and Brunsma, 2002), it is not clear that the public is aware of the extent to which racial identities are situational. A mixedrace identity can still be perceived as a fixed one- not changing according to context or life stage- even if it is a more complex type of racial identity than previously recognized. And retaining the idea of racial identities as fixed does little to dispel the notion of race as a biological indicator. As in the case of the animals and plants that we cross-breed, we can recognize their hybrid origins without rejecting the notion that their differences and mixture are rooted in biology.

The endurance of essentialist notions of race in contemporary discourse about multiracial people is evident. For example, the politician Barack Obama is routinely described as having a wondrous ability to connect with both black and white voters. Not only are these the poles of the American racial spectrum, but they are also his hereditary racial communities: he can appeal to both blacks and whites because he is black and white. He has a "natural" connection that is not very far from a $19^{\text {th }}$-century German Romantic vision of Volk bonds. The feeling that his bond to blacks and whites is rooted in his DNA- rather than culture- is underscored by the general oversight of the connections that his early years in Hawaii and Indonesia might afford. Does his mixedness and background also make him appealing to Asian Americans or native Hawaiians? If it were his cultural exposure that explained his ability to touch different kinds of people, we might expect greater examination of his ties to Asian Americans, and less of his bond with blacks, having grown up with a white mother and grandparents. Instead, it is his ostensibly biological makeup that is implicitly linked to his political success.

In short, multiple-race classification does not necessarily attack the underlying premise of the existence of races (Nobles, 2000), although it may complicate it. By asking individuals to combine options from a menu with a fixed number of items, the multiple-race standards do not call into question the five categories it deems racial groups. Not only does it retain the ethno-racial pentagon (Hollinger, 1995), but it further validates the collection of racial statistics. It perpetuates the idea that all people can and should be categorized in racial terms. So while the option to identify with more than one race may feel personally liberating to some, it is not the true revolution that some would make it out to be.

In this vein, it is important to realize that in the short period since the government's 1997 introduction of multiple-race classification, the idea of race as a genetic marker has not receded, but rather has enjoyed a striking revival among American scientists and medical practitioners (Henig, 2004; Lee, Mountain and Koenig, 2001). In other words, the increased visibility of multiracial America has not precluded a growing interest in identifying racial groups with genetic makeup ${ }^{12}$. If anything, hybridity has been cleverly embraced by new "recreational genomics" companies that offer to genetically determine the racial components of Americans' mixed backgrounds (Wade, 2002). Geneticists have also applied their skills to decoding the racial makeup of entire populations, such as that of Brazil (Pena et al., 2000) or of the American triracial isolate group known as the Melungeons (McGowan, 2003). Although the researchers who have insisted most strongly that race is written in our DNA have largely sidestepped the Hispanic population when making such claims (despite its prominence as the largest minority group in the nation), the new visibility of mixed-race people has not dealt much of a blow to the premise that race is an essential biological quality. Instead, 
hybridity has fit in nicely with geneticists' attempts to cast the human family tree in racial terms. Although the percentages of different types of racial ancestry that a recreational-genomics company like DNAPrint produces may seem more precise and "scientific," they are simply high-tech versions of the older blood-quantum language we have long used to talk about racial mixture: the person who is "half this, half that" or "three-quarters this, one-quarter that." The lessons that the recognition of multiracialism was supposed to teach us- about the social construction of racial categories and their malleability- appear to have been lost so far on scientist and layman.

\section{Multiple-race classification: new interpretations of the nation's demography}

The likelihood that the official recognition of mixed-race Americans will lead to a racism-free, "postracial" future is dubious. Nor has it resulted in the breakdown of civil rights policy or the wholesale statistical conversion of the black population into mulattoes. In short, neither the brooding fears nor the ardent hopes concerning the advent of multiple-race classification seem likely to be realized.

Yet the revision of the government's classification practices may have a meaningful impact on another, overlooked realm of American race-making: the way in which we racialize and count the nation's Hispanic population. In other words, the most important implications of the switch to multiple-race reporting lay not in the predictions described above, but in demographic developments that are not usually linked to the multiracial population. Not only are there many parallels between our racial conceptualization of Hispanics and multiracial people, but a common historical moment shapes attitudes about the racial identity of both. As a result, the process of adopting multiple-race classification may both affect and illuminate the nation's approach to the categorization of Latinos.

\section{The Racial Classification of Hispanics}

As explained above, the federal race standards have never deemed Hispanics a racial group. Instead, Hispanics are defined as a "cultural" or "ethnic" group, so that they "can be of any race." However, popular conventions, as well as media, academic, and even some government research, increasingly treat Hispanics as distinct from whites and blacks in a way that has turned this grouping into an unofficial but de facto race category. For example, it is common to find references in these media to statistical findings that distinguish between white, black, and Hispanic outcomes. Treating Hispanics as a group that is different from- but comparable to- the clearly racial "white" and "black" categories sends the message that Latinos make up a third race. In this vein, Bonilla-Silva (2004) argues that the Latino presence is contributing to a shift in the United States' traditional racial hierarchy from a biracial dichotomy to a triracial structure.

The racialisation of Hispanicity is a function not just of external labeling by outsiders (Portes and MacLeod, 1996), but also of their refusal in large numbers to adopt the white/black nomenclature that has traditionally constituted the principal axis of racial classification in the United States. On each of the last three censuses, roughly 40 
percent of Hispanics identified themselves as "Some other race" (Rodríguez, 2000), often writing in "Hispanic," "Latino," or a national designator such as "Mexican" or "Peruvian." Similarly, a 2002 survey found that when asked to identify with one of the five ${ }^{13} \mathrm{OMB}$ racial categories, 56 percent of the Latino respondents either volunteered the terms "Hispanic" or "Latino" as being appropriate for them, or noted that they would prefer to see these terms included among the other categories (Pew Hispanic Center / Kaiser Family Foundation, 2002: 31). Again, this positioning as neither black nor white, but of a group comparable to those two, solidifies the equation of Hispanic identity with a racial affiliation. Instead of the Hispanic "other" group calling into question the socially-constructed nature of the well-established black and white "races", our longstanding acceptance of blacks and whites as racial rather than social groups limits our conception of Latinos to that of a third "race".

\section{Shared Dilemmas of Multiple-Race and Hispanic Classification}

In many ways, the advent of multiple-race enumeration sets the stage for a reevaluation of the racial classification of the Hispanic population. For one thing, Latinos exhibit many of the same "racial properties" as mixed-race people; that is, they occupy a similar social location in the United States' racial landscape. First and foremost, Hispanics for the most part can certainly be considered to be multiracial themselves. Although- like other Americans whose multiracial ancestry stems from our antebellum history- Hispanics are not often included in public discourse about multiracial America, their mixed American, African, and European roots are widely recognized. However, the widespread association in the U.S. between Latinos and lowskilled labor migration denies Hispanics the contemporary allure of multiraciality. As writer Danzy Senna noted of the beautiful Time magazine computer-morphed "new face of America" (described previously): "Of course, anyone could see that women just like the computer face they had created did exist in Puerto Rico, Latin America, and Spanish Harlem" (quoted in Streeter, 2003: 305). In other words, the inhabitants of Spanish Harlem are not usually equated with the glamorous "Generation E.A." (ethnically ambiguous) profiled in the "Sunday Styles" section of The New York Times (La Ferla, 2003).

Lee and Bean (2004) draw another link between Latinos and multiraciality when they note that Hispanics are more likely than non-Hispanics to identify with more than one race. On the 2000 census, 6.3 percent of Hispanics selected multiple races, whereas only 1.9 percent of the non-Hispanic population did so (Grieco and Cassidy, 2001: 10). So whether by virtue of their historical ancestry or their current self-identification patterns, there is good reason to think of Latinos as a multiracial population.

Given this premise of hybridity then, it is not surprising that Hispanics and the mixedrace share a similar racial location on other counts as well. First, they share a common rejection of the United States' rigid traditional racial dichotomy (Rodríguez, 2000: 16). The multiracial movement vocally protested the federal classification structure that previously required them to choose only one of the official groups (Nobles, 2000; Williams Forthcoming). The much larger Hispanic population, however, can be said to have voted silently, by consistently rejecting the official race categories at high rates, in favor of the "Some Other Race" option. Both strategies reflect a common insistence on self-definition, rather than acceptance of externally-derived taxonomies. 

of "brown" people, just as the classification of mixed-race people did. As described above, one of the public's misgivings about multiple-race classification was that it would permit mixed-race people to abandon communities of color by asserting their relationship to whites. Various observers have suggested that multiracial people will ultimately come to be accepted as white (Gans, 1999), or something close, like Lind's (1998) "beige majority" or Bonilla-Silva's (2004) "honorary whites." Similarly, the federal government's stand that Hispanics should identify themselves with one or more of the five official OMB races raises the question of whether Hispanics should identify as white. Of the OMB racial categories, "White" is the one that Latinos are by far the most likely to choose. On the 2000 census, 48 percent of Hispanics selected the "White" category, 6 percent chose more than one race, and 2 percent identified as black (Grieco and Cassidy, 2001: 10). On the 2002 National Survey of Latinos (Pew Hispanic Center / Kaiser Family Foundation, 2002), Hispanics were 10 times as likely to identify themselves as white as they were to select "Black or African American": 20 percent preferred the label "White," and 2 percent chose "Black or African American." Consequently, any attempt to impose the five standard racial categories on the Latino population is tantamount to reclassifying the group as white.

Third, both the multiracial and Hispanic populations call into question the dividing line between race and ethnicity. Mixed-race Americans have done so by asserting that their sense of self should be taken as definitive, regardless of others' perceptions (Daniel, 2002; Rockquemore and Brunsma, 2002; Root, 1992). In so doing, they stake a claim to the optional or voluntary dimension of identity that American social scientists have tended to ascribe to ethnic identification. Latinos blur the race/ethnicity distinction in another way, however: by gradually (though not irreversibly) making the transition from an ethnic group defined by language and culture, to a pan-ethnic racial group akin to blacks and whites. Indeed, the extent to which Hispanics are understood as a racial bloc is evinced by recent press reporting on Latinos' having outstripped blacks as the nation's largest minority group. And despite Directive 15's clear treatment of Hispanics as an ethnic and not a racial group, many government programs- such as population projection or civil rights enforcement- effectively treat Hispanics as a bloc akin to blacks or Asians. The agencies do this by disregarding the racial information that Hispanics provide, in favor of identifying them solely as Hispanic. For example, the Equal Employment Opportunity Commission recently proposed a revised race and ethnicity questionnaire that would inform respondents, "For these purposes, if you mark 'Yes, Hispanic or Latino,' your race will not be reported" (Equal Employment Opportunity Commission, 2003: 34967).

In summary, multiracial and Hispanic Americans share not only hybrid lineages, but also similarities in the way that mixed ancestry confounds traditional dividing lines between race categories and even between the very concepts of race and ethnicity.

\section{Implications of Multiracial Classification for the Hispanic Population}

The common racial properties of multiracial and Hispanic Americans make it natural to ask how the evolution of the classificatory regime for one might be reflected in changes for the other. Indeed, the introduction of official multiple-race reporting is meaningful for the racial interpretation of Latinos for two reasons. First, the bureaucratic process 
of adopting multiracial classification may directly shape future attempts to revise Statistical Directive 15's treatment of Hispanic categorization. Second, the shift to multiple-race data may offer insights into contemporary American thinking about race that can shed light on how the racial classification of Latinos may evolve in the future.

Most directly, the process that the office of Management and Budget undertook in the early 1990s to address the issue of multiracial categorization set a precedent for settling such classificatory questions. Vocal protest by multiracial organizations and individuals set in motion a bureaucratic round of self-examination that culminated in the first set of revisions to Directive 15 since its promulgation 20 years earlier. This suggests a path for Latino activists who might wish to lobby the government for a new approach to racial categorization. It must be noted, however, that the 1997 revisions may actually discourage further racial classification revisions in the medium term. The drawn-out process of soliciting public opinion, commissioning studies, deliberating, and instituting change- all under the watchful eyes of an engaged press and publicmay not be one that the Office of Management and Budget is eager to revisit before the 2010 census.

Yet even without a full-blown revision of the racial standards, the Census Bureau now appears likely to change its race and ethnicity questions in ways that will affect the Hispanic population more directly than any other. As a result, the racial treatment of Hispanics is likely to be at the heart of debates about census classification in 2010, just as the multiracial population was at the center of controversy about the census of 2000 . For the 2010 census, the Census Bureau is now planning to remove the "Some Other Race" option from its race question. Since this category has been used almost exclusively by Hispanics- they constituted 97 percent of the individuals who selected the "Some Other Race" box alone (Grieco and Cassidy, 2001)- the impact of its elimination will be felt almost solely by the Hispanic population ${ }^{14}$. This step is intended to force Latinos to choose from among the OMB official races only, ostensibly to bring census data in line with other federal agencies' racial data (Swarns, 2004) ${ }^{15}$. Regardless of its motivation, the likely outcome of this measure is for the Hispanic population to be recast as "white," at least in 2010. In this new version of the question of how to deal with multiracial people, the solution will again be to disregard the diversity of identities that result from self-reporting, and constrain them to fit our traditional black, white, red and yellow categories. Instead of an ethnoracial pentagon (Hollinger, 1995) or polygon, we will again mold the nation's diversity into an ethnoracial square. And we will likely do so at the expense of higher item non-response rates on the part of Latino respondents.

Given the vehemence with which Latinos have insisted they not be forced into our black and white boxes, some academics have called for a new "Hispanic or Latino" category to be added to the nation's racial standards. On the census form, this would effectively mean combining the separate race and Hispanic ethnicity questions into one. Kenneth Prewitt, former Director of the Census Bureau, has made this recommendation (Prewitt Forthcoming). Although this move would be offensive to those who interpret it as equating Hispanics with a "race", it might in fact underline the Census Bureau's and OMB's assertions that the race categories are social, not biological, in nature. Moreover, this seems to be the option that Hispanics themselves most prefer. 
59 Finally, in considering the implications of multiple-race reporting for the Hispanic population, we must ask if it is the deliberations about multiracial classification themselves, or rather the shared historical moment that is at issue. In other words, public discourse about the categorization of mixed-race people may be most relevant to Latinos simply because it reveals the contemporary attitudes and conditions that shape our enumeration of both groups. We have already seen that despite the shift to multiple-race reporting, the federal government continues to translate the data into single-race statistics in practice, signaling a real reluctance to discard our traditional racial categories. The same adherence to an "ethnoracial square" is evident in the Census Bureau's latest efforts to force the Latino population into the same categories.

But if there seems to be little flexibility in the range of groups that Americans consider to constitute races, the historical record suggests there may be greater latitude in where we place the boundaries between racial groups. Even if we are not willing to alter the set of races, we may be amenable to shifting the dividing lines between them, so that people who were once in one race are now in another. Our informal, unspoken decision rules for assigning individuals to races are central to the way we approach the racial enumeration of multiracial and Hispanic people.

61 Arguably the most important dividing line in the United States' racial hierarchy is that between whites and others. Although the concept of a "white" population has been with us since the United States' earliest history, many scholars have shown in detail that ideas about just who was white varied a great deal over time (Brodkin, 1998; Haney Lopez, 1996; Ignatiev, 1995; Jacobson, 1998). In other words, American society has shown much more flexibility about who belongs to which race than it has over the dogma that there are four races: white, black, yellow, and red. Hence it seems that through our official mechanism of recognizing races, we are not likely to create a new "brown" racial category to accommodate Hispanics, but will accept their placement within the white category.

62 If the rigidity of our racial taxonomy comes as no surprise, we might still ask why Hispanics would be located in the "white" category, despite their lower socioeconomic outcomes (e.g. in education and income) relative to others in this group. Here the size of the Latino population may hold the key. With Hispanics having recently outstripped blacks as the nation's largest minority, their racial categorization has important implications for the way we conceptualize the racial makeup of the United States as a whole. At a time when the share of the non-Hispanic white population is falling, Hispanics have the potential to play a pivotal role in turning the tide (Yancey, 2003). The prediction that whites will fall into the minority in the United States (i.e. less than 50 percent of the population) sometime in the mid-2 ${ }^{\text {st }}$ century would be reversed if the white population were to receive an emergency transfusion of Latino members. Thus the willingness to absorb Hispanics in the white population may reflect fears about the United States' losing its status as a white nation.

63 The possible amalgamation of the white and Latino populations of the United Stateswhether through intermarriage or by administrative fiat- warrants a look backward at the last historical expansion of the definition of whiteness. One hundred years ago, the nation was coping with a wave of immigrants such as Italians, Jews, and Slavs whose whiteness was uncertain; Jacobson (1998) argues there was a fracturation of whiteness in this period. At the same time, there was some fracturation of blackness as well: in 1910, mixed-race people still figured on the census, represented by the "mulatto" 
category. ${ }^{16}$ The simultaneous appearance of both multifaceted whiteness and multifaceted blackness parallels our present-day efforts at categorizing Latinos and other mixed-race people. We are puzzled about how to racially type our new immigrants- from Mexico, from the Caribbean, from India- and at the same time, we are grappling with the classification of those who claim hybrid lineages. In this light, our racialisation of both mixed-race and Hispanic people are expressions of a common drive to clarify, rebuild and strengthen racial identities that have become fractured.

If we look back to the early $20^{\text {th }}$ century, we find that the challenging multiplicity of racial categories was gradually consolidated back into the limited number that had previously characterized the United States' racial landscape. If this convention holds true in our case as well, it implies that both multiple-race classification, as well as our racial categorization of Hispanics, will not ultimately disturb- but rather will reinforce- our underlying belief that all human beings can be reduced to shades of red, yellow, white, and black.

\section{BIBLIOGRAPHY}

Bonilla-Silva Eduardo (2004) From Bi-Racial to Tri-Racial: Towards a New System of Racial Stratification in the U.S.A. Ethnic and Racial Studies 27, pp. 931-950.

Bratter Jennifer L. (2004) Assimilating Blackness? Multiple-Race Identification and African American Mate Selection, in Annual Meeting of the American Sociological Association. San Francisco, CA.

Brodkin Karen (1998) How Jews Became White Folks and What That Says about Race in America. New Brunswick, NJ: Rutgers University Press.

Brown Linda Joyce (1997) Assimilation and the Re-Racialization of Immigrant Bodies: A Study of TIME's Special Issue on Immigration, The Centennial Review 41, pp. 603-608.

Cavalli-Sforza Luigi Luca (2000) Genes, Peoples, and Languages, New York: North Point Press.

Chew Kenneth S.Y., David J. Eggebeen, and Peter R. Uhlenberg (1989) American Children in Multiracial Households, Sociological Perspectives 32, pp. 65-85.

Daniel G. Reginald (2002) More than Black? Multiracial Identity and the New Racial Order, Philadelphia, PA: Temple University Press.

Davis Floyd James (1991) Who is Black? One Nation's Definition, University Park, PA: Pennsylvania State University Press.

Edmonston Barry, Joshua Goldstein, and Juanita Tamayo Lott (1996) Spotlight on Heterogeneity: The Federal Standards for Racial and Ethnic Classification, Washington, DC: Committee on National Statistics, Commission on Behavioral and Social Sciences and Education, National Research Council. 
Equal Employment Opportunity Commission (2003), Agency Information Collection Activities: Revision of the Employer Information Report (EEO-1) Comment Request. Federal Register 68, pp. 34965-9.

Fears Darryl (2001) Mixed-Race Heritage, Mixed Emotions: In Census and Society, Question of Categories Yields Many Answers, Washington Post, pp. A1.

Forbes Jack D. (1993) Africans and Native Americans: The Language of Race and the Evolution of RedBlack Peoples, Urbana and Chicago: University of Illinois Press.

Gaines James R. (1993), From the Managing Editor, TIME, pp. 2.

Gans Herbert J. (1999) The Possibility of a New Racial Hierarchy in the 21st Century United States, in Michele Lamont ed, The Cultural Territories of Race: Black and White Boundaries,. Chicago and New York: University of Chicago Press and the Russell Sage Foundation, pp. 371-390.

Goldstein Joshua R. and Ann J. Morning (2002) Back in the Box: The Dilemma of Using MultipleRace Data for Single-Race Laws, in Joel Perlmann and Mary C. Waters Eds, The New Race Question: How the Census Counts Multiracial Individuals, New York and Annandale-on-Hudson, NY: Russell Sage Foundation and the Levy Economics Institute of Bard College, pp. 119-136.

Graham Hugh Davis (2002) The Origins of Official Minority Designation, in Joel Perlmann and Mary C. Waters Eds, The New Race Question: How the Census Counts Multiracial Individuals, New York and Annandale-on-Hudson, NY: Russell Sage Foundation and the Levy Economics Institute of Bard College, pp. 288-299.

Grieco Elizabeth M and Rachel C. Cassidy (2001) Overview of Race and Hispanic Origin, edited by U.S. Census Bureau. Washington, DC: U.S. Department of Commerce.

Haney Lopez Ian F. (1996) White by Law: The Legal Construction of Race, New York: New York University Press.

Harris David R. and Jeremiah Joseph Sim (2002) Who Is Multiracial? Assessing the Complexity of Lived Race, American Sociological Review 67, pp.614-627.

Harrison Roderick (2002) Inadequacies of Multiple-Response Race Data in the Federal Statistical System, in Joel Perlmann and Mary C. Waters Eds, The New Race Question: How the Census Counts Multiracial Individuals, New York and Annandale-on-Hudson, NY: Russell Sage Foundation and the Levy Economics Institute of Bard College, pp. 137-160.

Henig Robin Marantz (2004) «The Genome in Black and White (and Gray), The New York Times Magazine, pp. 46-51.

Hollinger D (1995) Postethnic America: Beyond Multiculturalism. New York: Basic Books.

Ignatiev Noel (1995) How the Irish Became White, New York: Routledge.

Jackson Nakazawa Donna (2003) «A New Generation is Leading the Way: What Young People of Mixed Race Can Tell Us About the Future of Our Children, Parade, pp. 4-5.

Jacobson Matthew Frye (1998) Whiteness of a Different Color: European Immigrants and the Alchemy of Race, Cambridge, MA: Harvard University Press.

Jones Rhett (1994) The End of Africanity? The Bi-Racial Assault on Blackness, The Western Journal of Black Studies 18, pp. 201-210.

La Ferla Ruth (2003) Generation E.A.: Ethnically Ambiguous, The New York Times, pp. 9-1, 9-9.

Lee Jennifer and Frank D. Bean (2004) America's Changing Color Lines: Immigration, Race/ Ethnicity, and Multiracial Identification, Annual Review of Sociology 30, pp. 221-242. 
Lee Sandra S.J., J. Mountain, and B. A. Koenig (2001) The Meanings of 'Race' in the New Genomics: Implications for Health Disparities Research, Yale Journal of Health Policy, Law andpEthics, pp. 33-75.

Lind Michael (1998), The Beige and the Black, The New York Times Magazine, pp. 38-39.

Malcomson Scott L., (2004) An Appeal Beyond Race, The New York Times, pp. 1.

Mcgowan Kathleen (2003) Where Do We Really Come From?, Discover 24, pp.58-63.

Morning Ann. (2000), Who Is Multiracial? Definitions and Decisions, Sociological Imagination 37, pp. 209-229.

Morning Ann (2003) New Faces, Old Faces: Counting the Multiracial Population Past and Present, in Herman DeBose and Loretta Winters Eds, New Faces in Changing America: Multiracial Identity in the 21st Century, Thousand Oaks, CA: Sage, pp. 41-67.

Nelson Jill (2000) Mixed Thoughts on Census Race Question, USA Today.

Nobles Melissa (2000), Shades of Citizenship: Race and the Census in Modern Politics, Stanford CA: Stanford University Press.

Obama Barack (2004) Dreams from my Father: A Story of Race and Inheritance. New York: Three Rivers Press.

Office Of Management And Budget (1997) Revisions to the Standards for the Classification of Federal Data on Race and Ethnicity, Washington, DC.

Office Of Management And Budget (2000) Guidance on Aggregation and Allocation of Data on Race for Use in Civil Rights Monitoring and Enforcement (Bulletin 00-02), Washington, DC.

Office Of Management And Budget (2000) Provisional Guidance on the Implementation of the 1997 Standards for the Collection of Federal Data on Race and Ethnicity, in Tabulation Working Group, edited by Interagency Committee for the Review of Standards for Data on Race and Ethnicity. Washington, DC.

Omi Michael and Howard Winant (1994) Racial Formation in the United States, New York: Routledge.

Owens Mitchell (2004) Surprises in the Family Tree, The New York Times, pp. F1, F4.

Pena Sergio D.J., Denise R. Carvalho-Silva, Juliana Alves-Silva, Vânia F. Prado, and Fabrício R. Santos, (2000), Retrato Molecular do Brasil, Ciência Hoje 27, pp. 16-25.

Perlmann Joel and Mary C. Waters Eds, (2002) The New Race Question: How the Census Counts Multiracial Individuals, New York and Annandale-on-Hudson, NY: Russell Sage Foundation and the Levy Economics Institute of Bard College.

Pew Hispanic Center / Kaiser Family Foundation, (2002) 2002 National Survey of Latinos: Summary of Findings, Menlo Park, CA and Washington, DC: Henry J. Kaiser Family Foundation and Pew Hispanic Center.

Pollard Kelvin M. and William P. O'hare (1999) America's Racial and Ethnic Minorities, Population Bulletin 54.

Portes Alejandro, and Dag Macleod (1996) What Shall I Call Myself? Hispanic Identity Formation in the Second Generation, Ethnic and Racial Studies 19, pp. 523-547.

Prewitt Kenneth (2005) Racial Classification in America: Where Do We Go From Here?, Daedalus: 134, pp. 5-17.

Puente Maria, and Martin Kasindorf (1999) The New Face of America: Blended Races Making a True Melting Pot, USA Today, pp. 1A, 13A. 
Raspberry William (1999) For Blacks, Mixed Feelings on Ancestry, The Star Ledger, Trenton, pp. A15.

Rockquemore Kerry Ann and David L. Brunsma (2002), Beyond Black: Biracial Identity in America, Thousand Oaks, CA: Sage.

Rodríguez Clara E. (2000) Changing Race: Latinos, the Census, and the History of Ethnicity in the United States. New York: New York University Press.

Root Maria P.P. (1992) A Bill of Rights for Racially Mixed People, in Maria P.P. Root Ed, Racially Mixed People in America, Newbury Park, CA: Sage Publications, pp. 3-14.

Sabbagh Daniel and Ann Morning (2004) The United States: Comparative Study on Data Collection Aiming to Measure the Extent and Impact of Discrimination in Certain Countries, Lyon: Economie et Humanisme.

Schemo Diana Jean (2000) Despite Options on Census, Many to Check 'Black' Only The New York Times, pp. A1, A10.

Sollors Werner Ed. (2000) Interracialism: Black-White Intermarriage in American History, Literature, and Law. Oxford: Oxford University Press.

Spencer Jon Michael (1997) The New Colored People: The Mixed-Race Movement in America. New York: New York University Press.

Streeter Caroline A. (2003). The Hazards of Visibility: 'Biracial' Women, Media Images, and Narratives of Identity, in Herman DeBose and Loretta Winters Eds, New Faces in Changing America: Multiracial Identity in the 21st Century, Thousand Oaks, CA: Sage, pp. 301-322.

Swarns Rachel L. (2004) Hispanics Debate Census Plan to Change Racial Grouping, The New York Times, pp. 21.

U.S. Census Bureau (1918) Negro Population 1790-1915» in Census Bureau, edited by U.S. Department of Commerce. Washington, DC: Government Printing Office.

Wade Nicholas (2002) For Sale: A DNA Test to Measure Racial Mix, The New York Times, p. F4.

Williams Kim, (Forthcoming) Race Counts: American Multiracialism and Post-Civil Rights Politics Ann Arbor, MI: University of Michigan Press.

Wilson Terry P. (1992) Blood Quantum: Native American Mixed Bloods, in Maria P.P. Root Ed, Racially Mixed People in America, Newbury Park, CA: Sage, pp. 108-125.

Winslow Olivia (2001) Does It All Add Up? New Census Race Categories Raise Questions about How They're Used, Newsday. New York, NY, pp. A5, A36.

Wolfe (2001) Land, Labor, and Difference: Elementary Structures of Race, The American Historical Review 106, pp. 866-905.

Yancey George (2003) Who Is White? Latinos, Asians, and the New Black/Nonblack Divide, Boulder, CO \& London: Lynne Rienner Publishers.

Zack Naomi Ed. (1995) American Mixed Race: The Culture of Microdiversity, Lanham, MD: Rowman \& Littlefield Publishers, Inc. 


\section{NOTES}

1. Although the change in racial classification standards was not limited to the U.S. census- it applied to all federal agencies' data collection efforts- I focus here on census-related discourse because in the public eye, the classification change was most closely associated with the decennial census.

2. See Graham (2002) for a historical account of the genesis of these bureaucratic categories.

3. This limited acknowledgment of European-descent multiracial groups only may have reflected simple ethnocentrism on the part of whites (Wilson 1992), but it likely also reflected the particular roles that such intermediary groups played in whites' conception of the boundaries between themselves and non-whites. As Patrick Wolfe (2001) has shown, racial classification as Indian, black, or white had important implications for individuals' relationships to propertynotably, whether they could own property, and under what conditions, or whether they were themselves considered property- and accordingly, regulating the status of such mixed-race people in the 18th and 19th centuries had ramifications for the whites who deemed themselves the only legitimate owners of property, whether land or labor.

4. This was the figure put forward by the Census Bureau itself early in the 20th century (U.S. Census Bureau 1918).

5. See Bratter (2004) for an empirical investigation of the extent to which mixed-race people's own marriage outcomes demonstrate an "assimilation" effect of the multiracial population.

6. See Puente and Kasindorf (1999) for additional mixed-race celebrity examples.

7. Speech excerpt reprinted in The New York Times, July 28, 2004, p. P8.

8. Note however that such statistical "passing" is void of any individual material benefit to respondents (though it might provide psychological benefits), unlike the real "passing" of the late $19^{\text {th }}$ and early $20^{\text {th }}$ centuries.

9. For more information on the federal government's use of racial statistics for antidiscrimination purposes, see Sabbagh and Morning (2004).

10. The government has not issued as definitive a statement about how to "bridge" older, singlerace data to the new, multiple-race data for longitudinal research. See however the "Provisional Guidance on the Implementation of the 1997 Standards for the Collection of Federal Data on Race and Ethnicity" (Office of Management and Budget 2000).

11. For examples of the argument that biological essentialism is the sine qua non of racism, see Cavalli-Sforza (2000) and Omi and Winant (1994).

12. See for example the recent special issues of Scientific American (December 2003) and Nature Genetics (November 2004) devoted to the question of whether race is biologically grounded.

13. The 1997 revision to Statistical Directive 15 added a fifth racial category, "Native Hawaiian or Other Pacific Islander." Only 0.3 percent of the U.S. population chose this category (alone or in combination with others) on the 2000 census (Grieco and Cassidy 2001).

14. If all responses that included "Some Other Race" either alone or in combination with other races are considered, Hispanics contributed 90 percent of such responses.

15. As noted previously, however, many federal users of racial and ethnic statistics do not appear to require race data from Hispanic respondents.

16. As Davis (1991) shows, however, the 1910 census really represented the tail end of a period in which multiple labels (e.g. "quadroon," “octoroon") were applied to people of African ancestry; it was the last U.S. census to use such labels. The process of solidifying blackness into a single category, governed by the "one-drop" rule, had begun in the mid-19th century. 


\section{ABSTRACTS}

In 1997, the United States' federal guidelines on racial classification were amended to permit individual respondents to identify themselves as members of more than one race. This measure, taken at the urging of a vocal community of mixed-race individuals and organizations, was seen by many as having important consequences. In this article I examine the predictions about the impact of multiple-race classification, and assess how accurate they have proved to be. I conclude however that neither the hopes nor fears associated with multiracial recognition have been realized. Instead, the most important legacy of the recognition of mixed-race America is likely to be its contribution to the debate about classifying a much larger segment of the population: the Hispanic community.

La classification multiraciale dans le recensement américain : mythe, réalité et impact futur.

En 1997, les directives fédérales des États-Unis sur la classification raciale furent amendées afin de permettre aux répondants individuels de s'identifier comme membres de plus d'une " race » (dans le sens anglo-saxon du terme, qui n'a aucune connotation biologique ou racialiste). Beaucoup considéraient que cette mesure, prise sous la pression de la communauté des personnes et organisations se revendiquant de "race mixte", allait avoir d'importantes conséquences. Dans cet article, j'examine les prévisions quant à l'impact de la classification multiraciale et j'évalue leur pertinence au regard des résultats obtenus. Je conclue que ni les espoirs, ni les craintes associées à la reconnaissance multiraciale ne se sont été concrétisées. Au lieu de cela, l'apport le plus important de la reconnaissance du caractère multiracial de l'Amérique sera probablement sa contribution au débat relatif à la classification d'un segment beaucoup plus large de la population: les Hispaniques.

Clasificación multirracial en el censo de Estados Unidos : Mito, realidad y impacto futuro. En 1997,las directivas federales de Estados Unidos sobre la clasificación racial fueron modificadas para permitir a los individuos de identificarse como miembros de mas de una raza. Muchos consideraron que esta medida, que respondía a la presión común de personas y organizaciones reivindicándose de "raza mixta", tendría consecuencias importantes. En este articulo, examino las previsiones sobre el impacto de la clasificación multirracial, y evalúo la pertinencia de estas comparándolas con los resultados obtenidos. Concluyo que no se han concretizado ni las esperanzas ni los temores asociados al reconocimiento multirracial. Finalmente el principal aporte del reconocimiento del carácter multirracial de los Estados Unidos será probablemente su contribución al debate sobre la clasificación de los Hispano-Americanos, un segmento mucho mas ancho de la población.

INDEX

Geographical index: États-Unis

Mots-clés: ethnicisation, méthodologie, recensement, statistiques 


\section{AUTHOR}

\section{ANN MORNING}

Assistant Professor, Department of Sociology, New York University, 269 Mercer St., Rm. 445, New York, NY 10003-6687, USA, ann.morning@nyu.edu. 